\title{
Mineralogical, numerical and analytical studies of the coupled oxidation of pyrite and coal
}

\author{
K. A. Evans ${ }^{1, *}{ }^{\dagger}$, C. J. Gandy ${ }^{2}$ and S. A. Banwart ${ }^{1}$
}

${ }^{1}$ Department of Civil and Structural Engineering, University of Sheffield, Mappin St, Sheffield S1 3JD, UK

${ }^{2}$ School of Engineering and Geosciences, University of Newcastle upon Tyne, Newcastle upon Tyne NE1 7RU, UK

\section{ABSTRACT}

Mineralogical, bulk and field leachate compositions are used to identify important processes governing the evolution of discharges from a coal spoil heap in County Durham. These processes are incorporated into a numerical one-dimensional advective-kinetic reactive transport model which reproduces field results, including gas compositions, to within an order of magnitude. Variation of input parameters allows the effects of incorrect initial assumptions on elemental profiles and discharge chemistry to be assessed. Analytical expressions for widths and speeds of kinetic reaction fronts are developed and used to predict long-term development of mineralogical distribution within the heap. Results are consistent with observations from the field site. Pyrite oxidation is expected to dominate $\mathrm{O}_{2}$ consumption in spoil heaps on the decadal timescale, although $\mathrm{C}$ oxidation may stabilize contaminants in effluents on the centennial scale.

KEYWORDs: reactive transport modelling, redox, pyrite dissolution, acid mine drainage, weathering.

\section{Introduction}

RESEARCH into the interaction between mining waste material and the environment is driven by the need to characterize, understand, remediate and, ultimately, predict the contamination which frequently emanates from such sites (e.g. Banks et al., 1997, Younger, 2000; Malmstrom et al., 2000). Additionally, processes occurring can be analogous to those occurring in supergene environments (Capitan et al., 2001) and in other situations where infiltrating fluids are far from equilibrium with reactive solids and where low temperatures and rapid transport lead to kinetically controlled reactions. Mining sites have the added advantage that changes may be observed in real time.

The principal cause of contamination at the majority of mine-waste sites is the microbially catalysed oxidative dissolution of pyrite

* E-mail: katy.evans@csiro.au

DOI: $10.1180 / 0026461036720107$

${ }^{\dagger}$ Present address: CSIRO Exploration and Mining, Box 312, Clayton South, Victoria 3169, Australia
(Nordstrom and Southam, 1997), in which either $\mathrm{O}_{2}$ or ferric Fe may act as an electron acceptor via reactions 1 and 2. Ferric Fe is regenerated from the ferrous products of reactions 1 and 2 by reaction 3. Further acidity is released by the precipitation of ferric oxyhydroxides, reaction 4 .

$$
\begin{gathered}
\mathrm{FeS}_{2(\mathrm{~s})}+\frac{7}{2} \mathrm{O}_{2(\mathrm{aq})}+\mathrm{H}_{2} \mathrm{O}_{(\mathrm{aq})} \rightarrow \\
\mathrm{Fe}^{2+}{ }_{(\mathrm{aq})}+2 \mathrm{SO}_{4}^{2-}{ }_{(\mathrm{aq})}+2 \mathrm{H}^{+}{ }_{(\mathrm{aq})} \\
14 \mathrm{Fe}^{3+}{ }_{(\mathrm{aq})}+\mathrm{FeS}_{2(\mathrm{~s})}+8 \mathrm{H}_{2} \mathrm{O} \rightleftharpoons \\
2 \mathrm{SO}_{4}^{2-}{ }_{(\mathrm{aq})}+15 \mathrm{Fe}^{2+}{ }_{(\mathrm{aq})}+16 \mathrm{H}^{+}{ }_{(\mathrm{aq})} \\
\mathrm{Fe}^{2+}{ }_{(\mathrm{aq})}+\frac{1}{4} \mathrm{O}_{2(\mathrm{aq})}+\mathrm{H}^{+}{ }_{(\mathrm{aq})} \rightarrow \mathrm{Fe}^{3+}{ }_{(\mathrm{aq})}+\frac{1}{2} \mathrm{H}_{2} \mathrm{O}_{(\mathrm{aq})} \\
\mathrm{Fe}^{3+}{ }_{(\mathrm{aq})}+3 \mathrm{H}_{2} \mathrm{O}_{(\mathrm{aq})} \rightleftharpoons \mathrm{Fe}(\mathrm{OH})_{3(\mathrm{~s})}+3 \mathrm{H}^{+}{ }_{(\mathrm{aq})}
\end{gathered}
$$

Acidity produced by reactions 1 to 3 leads to low-pH solutions unless neutralized by rapidly dissolving alkalinity-producing minerals such as calcite (reaction 5) (Stromberg and Banwart, 1999). The reduction in $\mathrm{pH}$ accelerates rates of mineral dissolution and increases the mobility of potentially toxic metals. Other important processes at coal-mining sites are the oxidation 
of carbonaceous material (reaction 6), the slow production of alkalinity by the dissolution of clay minerals such as kaolinite (reaction 7) and illite (reaction 8), and the acidity-releasing precipitation of $\mathrm{Al}$ and $\mathrm{Fe}$ oxyhydroxides by reactions 4 and 9 , and hydroxysulphate minerals of the jarosite-alunite series, reactions 10 and 11 .

$$
\begin{gathered}
\mathrm{CaCO}_{3(\mathrm{~s})}+\mathrm{H}^{+} \rightarrow \mathrm{Ca}^{2+}{ }_{(\mathrm{aq})}+\mathrm{HCO}_{3}^{-}(\mathrm{aq}) \\
\mathrm{CH}_{2} \mathrm{O}_{(\mathrm{s})}+\mathrm{O}_{2(\mathrm{aq})} \rightarrow \mathrm{CO}_{2(\mathrm{aq})}+\mathrm{H}_{2} \mathrm{O} \\
\mathrm{Al}_{2} \mathrm{Si}_{2} \mathrm{O}_{5}(\mathrm{OH})_{4(\mathrm{~s})}+6 \mathrm{H}^{+}{ }_{(\mathrm{aq})} \rightarrow \\
2 \mathrm{H}_{4} \mathrm{SiO}_{4(\mathrm{aq})}+2 \mathrm{Al}^{3+}{ }_{(\mathrm{aq})}+\mathrm{H}_{2} \mathrm{O} \\
\mathrm{KAl}_{3} \mathrm{Si}_{3} \mathrm{O}_{10}(\mathrm{OH})_{2(\mathrm{~s})}+10 \mathrm{H}^{+}{ }_{(\mathrm{aq})} \rightarrow \\
3 \mathrm{H}_{4} \mathrm{SiO}_{4(\mathrm{aq})}+3 \mathrm{Al}^{3+}{ }_{(\mathrm{aq})}+\mathrm{K}^{+}{ }_{(\mathrm{aq})} \\
\mathrm{Al}^{3+}{ }_{(\mathrm{aq})}+3 \mathrm{H}_{2} \mathrm{O}_{(\mathrm{aq})} \rightleftharpoons \mathrm{Al}(\mathrm{OH})_{3(\mathrm{~s})}+3 \mathrm{H}^{+}{ }_{(\mathrm{aq})} \\
3 \mathrm{Fe}^{3+}{ }_{(\mathrm{aq})}+\mathrm{K}^{+}{ }_{(\mathrm{aq})}+2 \mathrm{SO}_{4}{ }^{2-}{ }_{(\mathrm{aq})}+6 \mathrm{H}_{2} \mathrm{O}_{(\mathrm{aq})} \rightleftharpoons \\
\mathrm{KFe}_{3}\left(\mathrm{SO}_{4}\right)_{2}(\mathrm{OH})_{6(\mathrm{~s})}+6 \mathrm{H}^{+}{ }_{(\mathrm{aq})} \\
3 \mathrm{Al}^{3+}{ }_{(\mathrm{aq})}+\mathrm{K}^{+}{ }_{(\mathrm{aq})}+2 \mathrm{SO}_{4}^{2-}{ }_{(\mathrm{aq})}+6 \mathrm{H}_{2} \mathrm{O}_{(\mathrm{aq})} \rightleftharpoons \\
\mathrm{KAl}_{3}\left(\mathrm{SO}_{4}\right)_{2}(\mathrm{OH})_{6(\mathrm{~s})}+6 \mathrm{H}^{+}{ }_{(\mathrm{aq})}
\end{gathered}
$$

Much study has been devoted to details of rates and mechanisms of pyrite oxidation (e.g. Baldi et al., 1992; Martello et al., 1994; Williamson and Rimstidt, 1994). However, it is difficult to predict water quality or timescales of contamination by applying results derived in the laboratory to field sites, or even from the extrapolation of results between field sites. One reason for this is that scaling corrections are required to account for variation in reaction rates between laboratory and field, which can be up to three orders of magnitude (Malmstrom et al., 2000). These variations result from differences in $\mathrm{pH}$, microbiology, grain size, hydrology, bulk-rock composition and other rate-controlling factors such as oxygen concentration. Further, interactions between reactions 1 to 11 are rarely considered, in spite of potentially significant effects. One interaction particularly pertinent to prediction of coal spoil heap contamination is the coupled consumption of $\mathrm{O}_{2}$ by pyrite and organic material oxidation. Pyrite oxidation is generally acknowledged to be faster than carbon oxidation in the short term (compare Williamson and Rimstidt, 1994 with Chang and Berner, 1999); however, the slower rate and greater volumetric abundance of coal available for oxidation could lead to longterm control of $\mathrm{O}_{2}$ concentrations in pyrite depleted portions of the heap by organic material. In this case, a substantial fraction of the heap would remain unavailable as a source of pollution, reducing the expected contamination lifetime. In spite of the importance of this consideration, little is known of the distribution of $\mathrm{O}_{2}$ within spoil heaps, and of the relative rates of pyrite and coal oxidation in the natural environment. Studies of $\mathrm{O}_{2}$ concentrations within a reclaimed strip mine (Jaynes et al., 1972; Guo et al., 1994) revealed $\mathrm{O}_{2}$ penetration to depths of $12 \mathrm{~m}$, whereas mineralogical evidence from a tip in Yorkshire, England (Spears et al., 1971) suggested that access of oxygen was limited to the outer $1 \mathrm{~m}$.

The variability exhibited by the small number of available studies emphasizes the need for assessment of oxygen distribution on a site-bysite basis. Gas monitoring of boreholes is expensive and time consuming and is rarely performed. It may therefore be desirable to use a mineralogical proxy for this parameter. Correlation between $\mathrm{O}_{2}$ content and ferric minerals in a metal tailings environment was noted by Blowes (1991) suggesting that the distribution of ferric Fe-bearing minerals such as Fe oxyhydroxides and jarosites may be used to elucidate $\mathrm{O}_{2}$ distribution. However, the interpretation of such mineral distributions is complicated by the fact that minerals may provide a timeintegrated picture of the $\mathrm{O}_{2}$ distribution within the heap. To deconvolute current status and past evolution we need to understand the processes controlling ferric mineral precipitation and dissolution in a quantitative way.

Reactive transport modelling using codes such as PhreeqC provides an opportunity to investigate the consequences of interactions between the processes discussed above, and the sensitivity of predictions to poorly known parameters such as rates of $\mathrm{O}_{2}$ infiltration and coal oxidation. Coupled reactive transport models, which solve transport equations sequentially or simultaneously with expressions for mass-action constraints on chemical reactions, have been used to investigate the effects of flow on chemically complex systems by a number of workers (e.g. Walter et al., 1994; Zhu et al., 2001). However, kinetics are rarely incorporated into these models because of the increase in computational time required. This study uses field observations to identify suitable assumptions for reactive transport modelling of coal spoil material. Comparison of results with field data allows dissolution rates to be constrained, improving predictive capability for 
long-term heap evolution. Results are also used to form simplified analytical expressions for widths and velocities of reaction fronts, and to predict consequences of different relative rates of pyrite and organic matter oxidation for long term development of $\mathrm{O}_{2}$ distribution in spoil heaps. Implications for interpretation of discharge chemistry and long-term prediction of effluent characteristics are discussed. Possible diagnostic minerals for determination of $\mathrm{O}_{2}$ distribution are identified, and their potential usefulness is assessed.

\section{Study area}

Morrison Busty coal spoil heap, situated close to the village of Quaking Houses in County Durham, UK (Fig. 1), is composed of $\sim 1 \mathrm{M}$ tonnes of grey and black weathered shale, ash, coal and coal dust. The heap is built on glacial clay and drift deposits which overlie Carboniferous Coal Measures beds. The areal extent of the heap is $\sim 35$ hectares and the height ranges from 0.5 to $10 \mathrm{~m}$. Dumping between 1922 and 1981 was followed by application of top soil and attempts at revegetation (Kemp and Griffiths, 1999). In 1986-87 a deep road cutting was created through the tip. At this point $\mathrm{Fe}$ and acidity loadings in tip effluents increased significantly (Jarvis and Younger, 1999). The heap is relatively well characterized, having been the subject of an experimental pilot remediation wetland scheme from 1997 onwards (Jarvis and Younger, 1999).

\section{Materials and methods}

\section{Mineralogical and field investigations}

Spoil material was collected during drilling for installation of water and gas sampling boreholes. Borehole $\mathrm{BH} 7$, installed for water monitoring purposes in 1996 (Pritchard, 1997) provided samples prefixed by AP. Gas monitoring holes, 2001A, 2001B and 2001C were drilled using a continuous flight auger, to 6,4 and $2 \mathrm{~m}$ deep respectively. The holes are located at the corners of an equilateral triangle of side approximately $10 \mathrm{~m}$ with $\mathrm{BH} 7$ at its centre. During construction of $2001 \mathrm{~A}, \mathrm{~B}$ and $\mathrm{C}$ the bit was lifted after every metre of drilling, and material was inspected before subsamples were taken for bulk and mineralogical investigation. Samples were refrigerated to $4^{\circ} \mathrm{C}$ as soon as practical after sampling. Gas sampling took place via a 1" inside-diameter screwed flush butt-jointed HDPE pipe, slotted for sample collection over a $0.5 \mathrm{~m}$ interval at the base of the hole. The hole was lined with coarse gravel

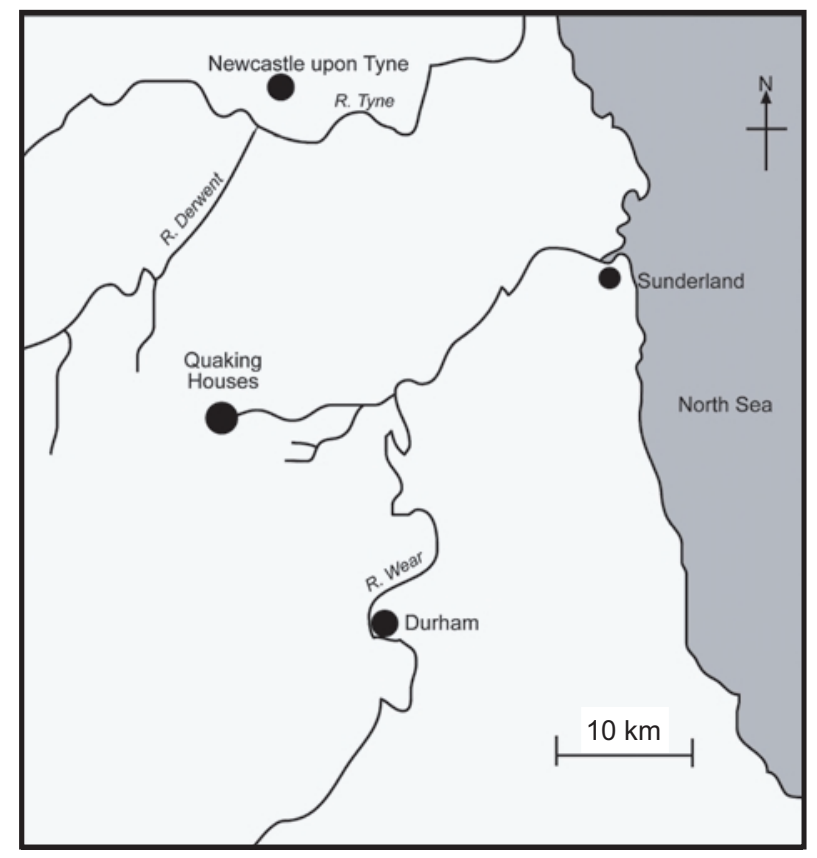

FIG. 1. Location of field site. 


\section{K. A. EVANS ETAL.}

over the gas sampling depth, with a bentonite seal applied above this. Monthly gas sampling using a LMSx Landfill Monitoring System is in progress. Preliminary results are presented in Table 1. Effluents from the tip and groundwater from borehole $\mathrm{BH} 7$ are sampled monthly; details of sampling methods can be found in Jarvis and Younger (1999).

Bulk compositions of samples AP1 (top of tip) to AP7 (bottom) were determined by X-ray fluorescence (XRF) at the British Geological Survey at Keyworth, UK. Major element concentrations were measured on fused glass beads and selected trace elements $(\mathrm{Ni}, \mathrm{Cu}, \mathrm{Zn}, \mathrm{As}, \mathrm{Pb})$ on pressed powder pellets. Sulphur was measured by LECO analysis at the Assay Office, Sheffield. Relevant results are shown in Table 2. Correlations between depth and bulk parameters were calculated and are presented in Table 3. $\mathrm{X}$-ray diffraction (XRD) was performed on powdered sub-samples of AP1 to AP7 using a Philips PW1730/10 diffractometer with DW1373 goniometer and $\mathrm{Cu}-K \alpha$ radiation. Randomly oriented samples were analysed in steps of $0.02^{\circ} 2 \theta$ at $2^{\circ} \min ^{-1}$. Estimates of modal proportions of minerals were made from XRD traces
TABLE 1. Gas compositions from wells at Quaking Houses. It is likely that the proportion of the gas which is unaccounted for is $\mathrm{N}_{2}$.

\begin{tabular}{lccc}
\hline Depth (m) & $\mathrm{CH}_{4}(\%)$ & $\mathrm{O}_{2}(\%)$ & $\mathrm{CO}_{2}(\%)$ \\
\hline 2 & n.d. & 16 & 2.6 \\
4 & n.d. & n.d. & 5.6 \\
6 & n.d. & n.d. & 5.5 \\
& & & \\
\hline
\end{tabular}

n.d. - not detected.

The accuracy of the detector is $\pm 0.1 \%$ for $\mathrm{CO}_{2}$ and $\pm 0.5 \%$ for $\mathrm{O}_{2}$. Detection limits are $0.2 \%, 0.5 \%$ and $0.1 \%$ for $\mathrm{CH}_{4}, \mathrm{O}_{2}$ and $\mathrm{CO}_{2}$, respectively.

using SIROQUANT, a computer package which utilizes the Rietveld method to refine calculated XRD patterns against the profile of a measured pattern (Taylor, 1991), allowing, theoretically, standardless quantitative phase analysis. Comparison of calculated modes with bulk composition constraints suggests that this method is semi-quantitative, at least for the samples analysed here. However, relative differences in proportion between samples are likely to

TABLE 2. Bulk compositions of spoil heap samples. Major element values are in wt.\% oxide. Sulphur is in wt.\% element, trace metals are in $\mathrm{ppm}$. Some portion of the $\mathrm{S}$ content is included in the mass balance both as LOI and as S, but this is not sufficient to significantly affect totals.

\begin{tabular}{lrrrrrrr}
\hline & AP1 & AP2 & AP3 & AP4 & AP5 & AP6 & AP7 \\
\hline Depth (m) & 1.25 & 2.25 & 3.25 & 4.25 & 5.25 & 6.25 & 7.25 \\
$\mathrm{SiO}_{2}$ & 30.67 & 35.18 & 37.94 & 34.68 & 36.29 & 33.24 & 35.17 \\
$\mathrm{TiO}_{2}$ & 0.63 & 0.72 & 0.73 & 0.65 & 0.76 & 0.73 & 0.77 \\
$\mathrm{Al}_{2} \mathrm{O}_{3}$ & 15.94 & 21.06 & 18.24 & 19.24 & 21.93 & 20.1 & 20.28 \\
$\mathrm{Fe}_{2} \mathrm{O}_{3}$ & 2.28 & 2.65 & 2.54 & 7.63 & 4.91 & 5.27 & 5.78 \\
$\mathrm{MgO}$ & 0.41 & 0.44 & 0.55 & 0.52 & 0.6 & 0.46 & 0.48 \\
$\mathrm{CaO}$ & 0.1 & 0.09 & 0.28 & 0.36 & 0.08 & 0.05 & 0.15 \\
$\mathrm{Na} 2 \mathrm{O}$ & 0.21 & 0.16 & 0.21 & 0.18 & 0.19 & 0.16 & 0.19 \\
$\mathrm{~K} 2 \mathrm{O}$ & 1.67 & 1.71 & 2.68 & 2.1 & 2.18 & 1.73 & 1.91 \\
$\mathrm{BaO}$ & 0.06 & 0.07 & 0.09 & 0.06 & 0.06 & 0.06 & 0.07 \\
$\mathrm{LOI}$ & 47.15 & 36.86 & 36.23 & 34.21 & 32.57 & 37.97 & 34.82 \\
$\mathrm{Total}$ & 99.12 & 98.94 & 99.49 & 99.63 & 99.57 & 99.77 & 99.62 \\
$\mathrm{~S}$ & 0.7 & 0.55 & 1.11 & 2.72 & 1.64 & 9.3 & 1.77 \\
$\mathrm{Ni}$ & 25 & 37 & 21 & 48 & 52 & 48 & 42 \\
$\mathrm{Cu}$ & 28 & 184 & 22 & 80 & 274 & 183 & 107 \\
$\mathrm{Zn}$ & 23 & 121 & 95 & 106 & 312 & 141 & 63 \\
$\mathrm{As}$ & 29 & 36 & 72 & 166 & 113 & 108 & 118 \\
$\mathrm{~Pb}$ & 72 & 72 & 88 & 88 & 81 & 57 & 68 \\
& & & & & & & \\
\hline
\end{tabular}




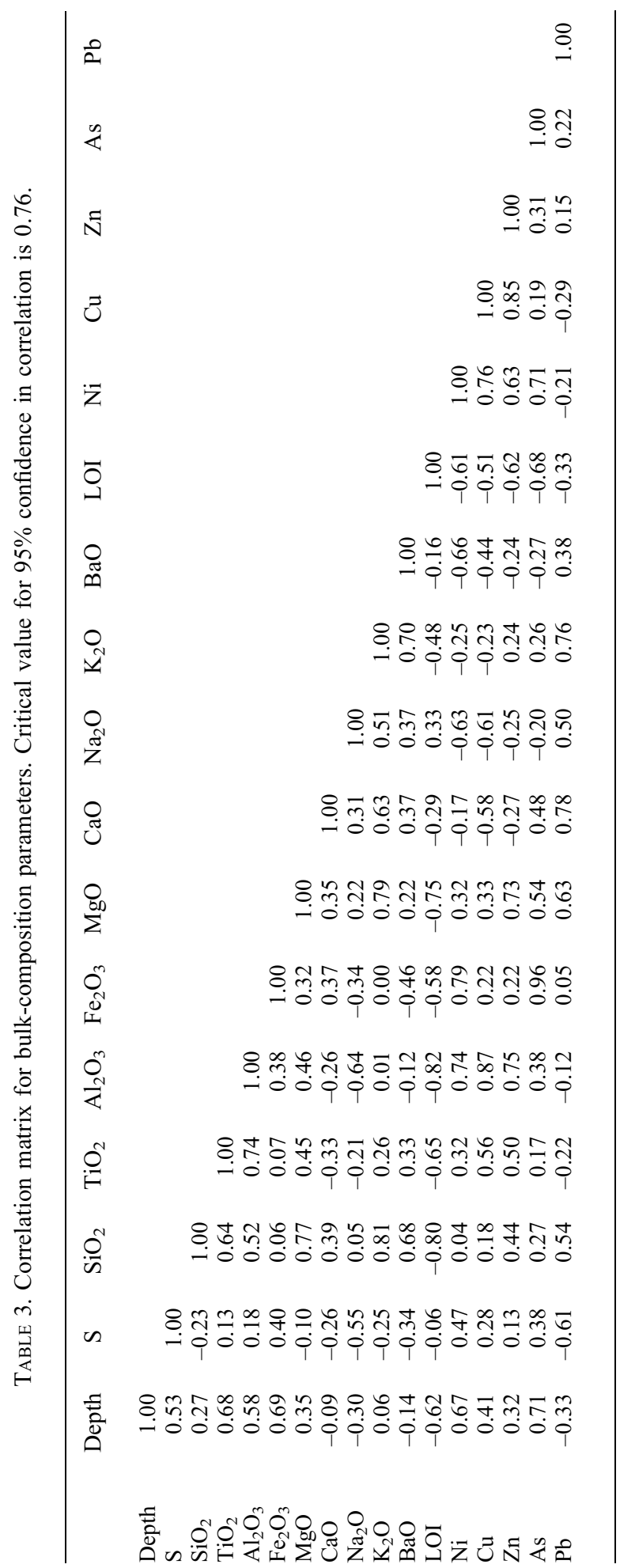


be robust. Trends also agree with field mineralogical observations made during drilling of $2001 \mathrm{~A}$, B and C, suggesting that they are qualitatively representative of conditions over the area of tip studied. Results are presented in Fig. 2. Unit-cell refinements for jarosite and alunite were perfomed using the WinXPow software.

\section{Numerical modelling}

Modelling of processes and rates focuses on effluent characteristics at $\mathrm{BH}$, as full consideration of compositional and hydrological heterogeneity of the system is beyond the scope of this study. Since the site of BH7 is close to the centre of the tip, it is unlikely that horizontal transport of gases or fluids in the unsaturated zone is significant. One-dimensional modelling was therefore thought to provide a reasonable analogue to existing transport processes. As a preliminary step, dimensionless numbers indicating the relative importance of advective, dispersive/diffusive and kinetic processes were calculated to enable simplifying assumptions to be applied to the conceptual model.

The Peclet number (equation 12) as defined by Appelo and Postma (1993) describes the ratio between advective and diffusive components of fluid modification of the profile.

$$
\mathrm{pe}=L / \alpha
$$

where $L$ is the characteristic length $(\mathrm{m})$ taken to be $1 \mathrm{~m}$, and $\alpha$ is the dispersivity for the spoil material (m). $\alpha$ is estimated here using $\alpha=3.5 \mathrm{~d}_{10}$ (Appelo and Postma, 1993), where $d_{10}$ is the maximum diameter of the smallest $10 \%$ of the particles. Note that dispersivity, a property of the solid material, is used in equations 12 and 13 in preference to a diffusion coefficient as it has been shown (Appelo and Postma, 1993) that spreading due to dispersivity significantly exceeds that due to diffusion under groundwater flow conditions. Calculated Peclet and Peclet-Dahmkohler numbers therefore apply to the fluid/solid system. Calculated Peclet numbers of 1000 for the system considered indicate that advective processes dominate. The Dahmkohler number describes the relative importance of kinetic and advective processes, and can be combined with the Peclet number to compare kinetic and dispersive spreading, equation 13.

$$
\text { pe-Da }=\nu / \alpha \kappa
$$

$v$ is fluid velocity and $\kappa$ is the reaction rate constant $\left(\mathrm{s}^{-1}\right)$. Values for $\kappa$, the reaction rate constant were obtained from literature studies (McKibben and Barnes, 1986; Bennet et al., 1999). The pe-Da number is $\sim 10^{6}$, indicating that kinetic processes will control the spreading of
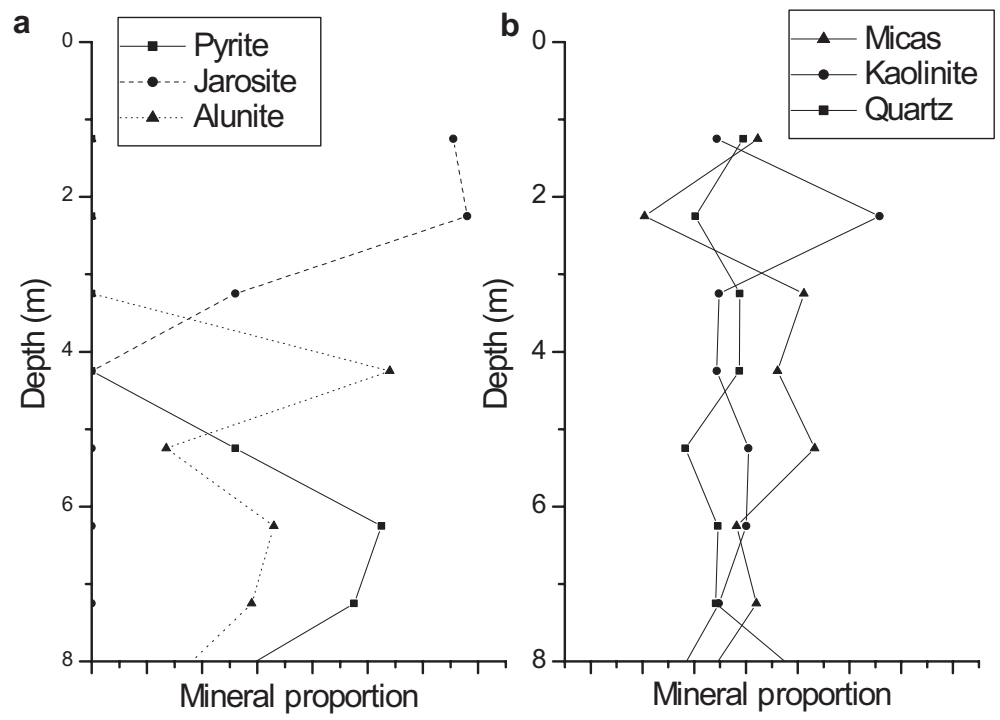

FIG. 2. Qualitative estimates of modal mineral proportions in samples from the spoil heap. Estimates calculated from XRD data using SIROQUANT (Taylor, 1991). 
reaction fronts for the velocities considered here. Explicit consideration of dispersion is therefore excluded from the modelling described below.

The vertical profile down the tip was envisaged as a series of cuboid boxes or cells, each containing 1 litre of water. Laboratory measurements of water content suggested a water-filled porosity of $20 \%$ by volume, and spoil content was calculated accordingly. Initial numbers of moles for each primary mineralogical component were calculated from bulk and mineral compositions. Initial mineralogy, dissolution rates and mechanisms are shown in Table 4. Dissolution rates for primary minerals are taken from the literature and adapted to the field situation as described below, while formation of secondary minerals is assumed to be uninhibited by kinetics. Flow is unsaturated, implying that gas-filled porosity coexists with the reactive water. The gas-filled porosity is considered to be inert and volumetrically invariant for the purposes of this exercise. Primary minerals, i.e. minerals considered to be present before weathering began, are pyrite $\left(\mathrm{FeS}_{2}\right)$, kaolinite $\left(\mathrm{Al}_{2} \mathrm{Si}_{2} \mathrm{O}_{5}(\mathrm{OH})_{4}\right)$, coal (C) and illite $\left(\mathrm{KAl}_{3} \mathrm{Si}_{3} \mathrm{O}_{10}(\mathrm{OH})_{2}\right)$. Analysis of material from $\mathrm{BH} 7$ and core from the gas-sampling holes revealed a negligible $\mathrm{Ca}$ content, therefore calcite was not considered, although it has been shown to have a significant effect on contaminant release at other sites (Stromberg and Banwart, 1999). Secondary minerals, i.e. minerals which may form as a result of weathering processes, considered are goethite $(\mathrm{FeOOH})$, amorphous aluminium hydroxide $\left(\mathrm{Al}(\mathrm{OH})_{3}\right)$, alunite $\left(\mathrm{KAl}_{3}\right.$ $\left.\left(\mathrm{SO}_{4}\right)_{2}(\mathrm{OH})_{6}\right)$ and jarosite $\left(\mathrm{KFe}_{3}\left(\mathrm{SO}_{4}\right)_{2}(\mathrm{OH})_{6}\right)$. These minerals are not initially present within modelled spoil but are set to precipitate once solutions reach chemical saturation with respect to one or more of them. Effects of solid solution between alunite and jarosite were not incorporated into the modelling.

Rates of dissolution for the primary minerals were assumed to be controlled by surface kinetic processes. The rate law for pyrite was taken from McKibben and Barnes (1986) and shows a halforder dependence on $\mathrm{O}_{2}$ concentration; this is appropriate for environments where $\mathrm{O}_{2}$ supply is limited. To account for differences in reactivity between field and laboratory environments, a low specific surface area of $1 \mathrm{~m}^{2}$ mole ${ }^{-1}$, consistent with BET surface areas of the spoil, was used. Slower rates of pyrite oxidation were also tested in the modelling. First order dissolution rate constants and surface areas for kaolinite were taken from the lower end of literature results (Walther, 1996; Nagy et al., 1991). Illite dissolution rates are not widely quoted in the literature, mainly because it is known to dissolve incongruently to produce nonstoichiometric K/Al ratios (Fanning and Keramidas, 1989). For the purposes of this study, congruent dissolution is assumed, as a limited degree of incongruency would have no effect on calculated results. A dissolution rate identical to that of kaolinite is used here. Coal oxidation rates under field conditions are also poorly known, as the bulk of investigations occur at much higher

TABLE 4. Initial quantities and dissolution rate expressions for minerals considered in modelling. $M$ is the number of moles of the mineral and $S A$ is the surface area in moles $\mathrm{m}^{-2}$, assumed to be 1,10 and 100 for pyrite, kaolinite and illite, respectively.

\begin{tabular}{|c|c|c|}
\hline Mineral & $\begin{array}{l}\text { Initial quantity } \\
\text { (moles per cell) }\end{array}$ & $\begin{array}{l}\text { Rate-controlling mechanisms and } \\
\text { rates for dissolution/precipitation }\end{array}$ \\
\hline Pyrite & 1.25 & ${ }^{1}$ Rate $=4.5 \times 10^{-8} \times M \times\left[\mathrm{O}_{2}\right]^{0.5} \times S A$ \\
\hline Kaolinite & 13.5 & ${ }^{2}$ Rate $=1 \times 10^{-12} \times M \times S A$ \\
\hline Illite & 5.25 & ${ }^{3}$ Rate $=1 \times 10^{-12} \times M \times S A$ \\
\hline Coal & 100 & ${ }^{4}$ Rate $=1 \times 10^{-9} \times M$ \\
\hline Jarosite & 0 & Equilibrium \\
\hline Alunite & 0 & Equilibrium \\
\hline Goethite & 0 & Equilibrium \\
\hline
\end{tabular}

\footnotetext{
${ }^{1}$ McKibben and Barnes (1986)

2 Nagy et al. (1991)

3 Assumed equal to kaolinite

${ }^{4}$ Bennet et al. (1999)
} 
temperatures and over shorter timescales than those applicable to this study (e.g. Jones et al., 1991). First order rate constants used here are laboratory estimates of oxidation rates in pyritic spoil calculated by Bennet et al. (1999). These are approximately one order of magnitude greater than those reported by Chang and Berner (1999), which were measured on non-pyritic spoil. Differences arise from variation in coal reactivity, experimental methods and observation timescales. Coal weathering produces $\mathrm{CO}_{2}$ which is assumed to remain dissolved in solution once produced. Clearly, in unsaturated spoil some gas transport out of the heap by diffusive processes is likely; it is also improbable that all oxidized coal forms $\mathrm{CO}_{2}$, as surface-oxidized species have been observed in laboratory studies by other workers (Chang and Berner, 1999). Predicted $\mathrm{CO}_{2}$ concentrations are therefore likely to be maxima. Initial quantities of secondary minerals were set to zero and their formation was assumed to take place at equilibrium with the solution: i.e. precipitation occurs when the solubility product of the mineral considered exceeds the solubility constant contained within the program database. Conversion between $\mathrm{Fe}$ (II) and $\mathrm{Fe}$ (III) species was also assumed to be equilibrium-controlled on the timescales considered. Oxygen addition was simulated by infiltration of $\mathrm{O}_{2}$-saturated water into the top cell at every time step at rates calculated from a Darcy fluid velocity of $0.02 \mathrm{~m} \mathrm{day}^{-1}$. Diffusion through pore space is not explicitly considered, although the $\mathrm{O}_{2}$ content of infiltrating water was increased in some model runs to assess the effect of $\mathrm{O}_{2}$ ingress by diffusion through airspaces in unsaturated spoil. The results are shown in Fig. 3 and compared to field results in Table 5.

The fluid velocity effectively determines the modelled rate of $\mathrm{O}_{2}$ addition to the heap. The combination of flow velocity and time step parameters also determines the length scale of the cells, $(L=V t)$, where $L$ is the length of a cell (m), $V$ is the average linear flow velocity (in $\mathrm{m} \mathrm{s}^{-1}$ ), and $t$ is the time step (s). Therefore, for an average linear velocity of $0.1 \mathrm{~m}^{-1 a y^{-1}}$ and a time step of $864 \mathrm{~s}$, the cell size is $1 \mathrm{~mm}$. Calculations were made using PhreeqC version 2.4.2
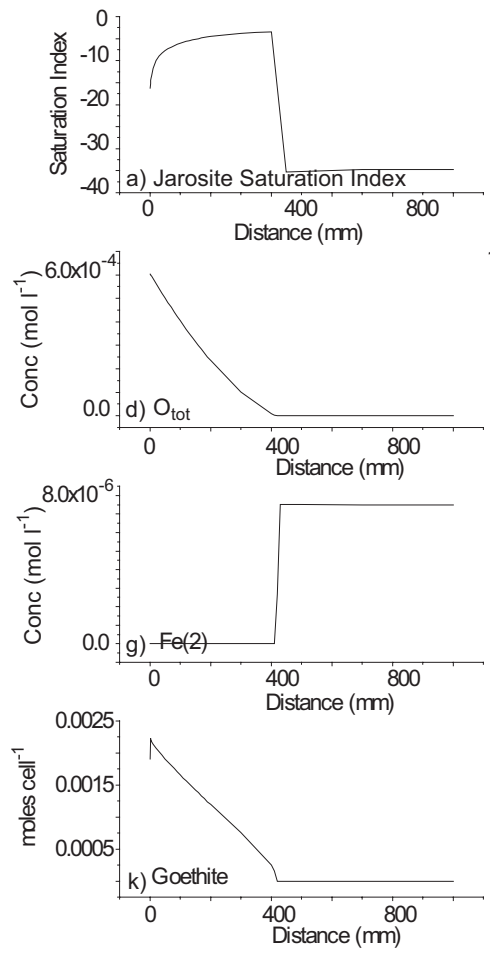
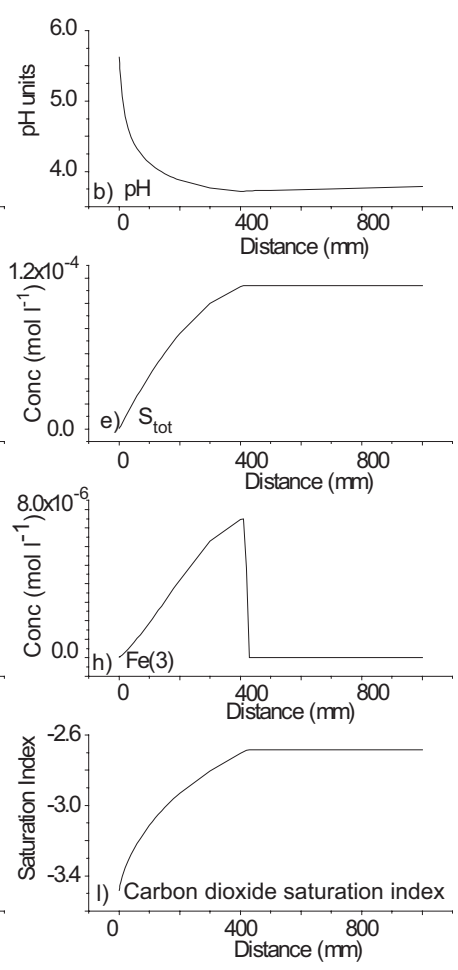
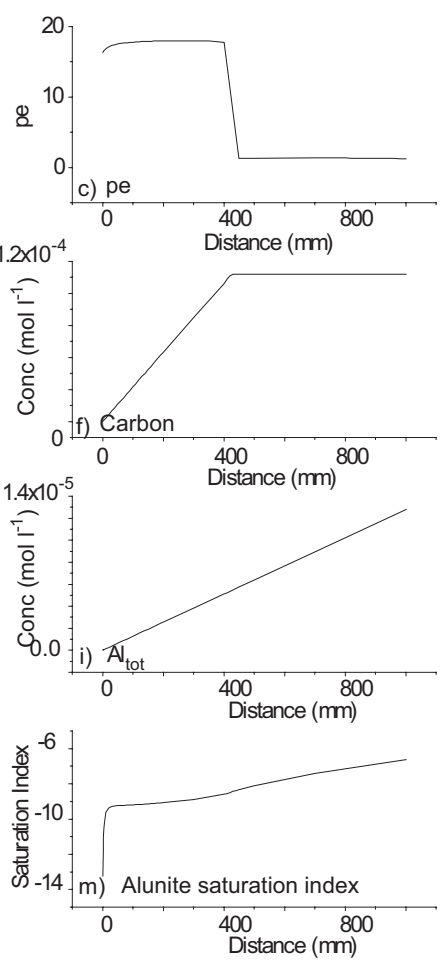

FIG. 3. Results of run 1. Saturation index is defined by $\log (\mathrm{IAP})_{\mathrm{obs}}-\log (\mathrm{IAP})_{\text {calc. }}$. Concentrations are in moles $1^{-1}$ of solution. 
TABLE 5. Comparing observed and modelled parameters. For runs 2 to 6 the figures are those calculated by the model at the bottom of the section on modelling.

\begin{tabular}{lcccccccccc}
\hline & $\mathrm{pH}$ & $\begin{array}{c}\mathrm{Fe}_{\text {tot }} \\
(\mathrm{ppm})\end{array}$ & $\begin{array}{c}\mathrm{Al}^{3+} \\
(\mathrm{ppm})\end{array}$ & $\begin{array}{c}\mathrm{K}^{+} \\
(\mathrm{ppm})\end{array}$ & $\begin{array}{c}\mathrm{SO}_{4}^{2-} \\
(\mathrm{ppm})\end{array}$ & $\mathrm{SI}_{\text {goethite }}$ & $\mathrm{SI}_{\mathrm{Al}(\mathrm{OH})_{3}(\mathrm{a})}$ & $\mathrm{SI}_{\text {jarosite }}$ & $\mathrm{SI}_{\text {alunite }}$ & $\mathrm{SI}_{\mathrm{CO}_{2}(\mathrm{~g})}$ \\
\hline Field $^{1}$ & 4.0 & 6 & 1 & 5 & 29 & -4 & -4 & -3 & & -8 \\
-1.3 & & & & & & & & & & \\
Field $^{2}$ & 4.0 & 6 & 1 & 5 & 29 & 7 & -5 & 3 & -2 & -1.3 \\
Run 1, ox & 3.7 & 0.4 & 0.2 & 0.04 & 11 & 5 & -6 & -3 & -8 & -2.7 \\
Run 1, red & 3.8 & 0.4 & 0.4 & 0.1 & 11 & 2 & -6 & -35 & -7 & -2.7 \\
Run 2 & 3.6 & 0.7 & 0.4 & 0.1 & 16 & -6 & -6 & -34 & -7 & -3.2 \\
Run 3 & 3.7 & 0.4 & 0.04 & 0.01 & 11 & -6 & -7 & -36 & -11 & -2.7 \\
Run 4 & 3.7 & 0.7 & 0.4 & 0.1 & 15 & -6 & -6 & -34 & -7 & -3.0 \\
Run 5 & 3.2 & 4 & 0.4 & 0.1 & 39 & 2 & -7 & -9 & -10 & -2.4 \\
Run 6 & 4.6 & 0.08 & 0.4 & 0.1 & 3 & -5 & -3 & -36 & -3 & -2.3 \\
& & & & & & & & & &
\end{tabular}

\footnotetext{
${ }^{1}$ Solution parameters taken from analysis of water extracted from BH7 on 19/12/2000. Saturation indices calculated at pe $=0$. The $\mathrm{CO}_{2}$ saturation index from measurement at $6 \mathrm{~m}$ in $2001 \mathrm{~A}$.

${ }_{2}^{2}$ Parameters for the same BH7 solution calculated for a pe value of 12 .
}

(Parkhurst and Appelo, 1999), with the Wateq4f database (Ball and Nordstrom, 1991). The advective transport model solves equation 14 , the expression for transport and reaction, using an explicit finite difference scheme that is forwards in time, and upwind for advective transport. The chemical interaction term $d q / d t$ for each element is calculated separately to the transport step in a split-operator scheme (Press et al., 1986). This means that for each time step, the advective displacement for the fluid is calculated, then a solution is found to the expressions for equilibrium and chemically controlled reactions.

$$
\frac{\partial C}{\partial t}=-v \frac{\partial C_{\mathrm{f}}}{\partial x}-\frac{\partial q}{\partial t}
$$

Advantages and disadvantages of the splitoperator scheme were discussed by Walter et al. (1994). Mineral dissolution rates described above are defined in the program using a BASIC interpreter facility. Geochemical kinetic reactions frequently result in 'stiff' sets of equations, in which rates of change of concentrations of the different chemical species vary over several orders of magnitude at each time step. To deal with this, PhreeqC uses a Runge-Kutta scheme to integrate rates over time, using up to six intermediate evaluations of derivatives. Time steps were divided into up to 10 sub-steps for the purposes of this integration. Further details of mathematical methods can be found in Parkhurst and Appelo (1999).
To explore the sensitivity of results to variation in input parameters, a number of additional runs were performed. Input parameters were varied, one at a time, across the ranges reported from literature and/or field studies. Details are summarized in Table 6 and results are shown in Fig. 4. Since the previous run showed no significant variation between timesteps 1000 and 10,000, runs of 2000 timesteps were performed.

\section{Analytical solution modelling}

Rates of $\mathrm{O}_{2}$ supply, groundwater velocities and mineralogical modes determine the speed at which kinetic reaction fronts move downwards through the heap, and hence the ultimate timescale of contamination. The mathematical theory behind equilibrium and kinetically controlled fronts has been discussed extensively in the

TABle 6. Details of additional runs for sensitivity analysis.

\begin{tabular}{ll}
\hline Run & \multicolumn{1}{c}{ Parameter variation } \\
\hline R2 & Reduce rate of organic matter oxidation by one OM \\
R3 & Reduce rate of kaolinite/illite dissolution by one OM \\
R4 & Increase rate of pyrite weathering by one OM \\
R5 & Increase oxygen supply by a factor of three \\
R6 & Increase rate of organic matter oxidation by one OM
\end{tabular}

OM: order of magnitude 

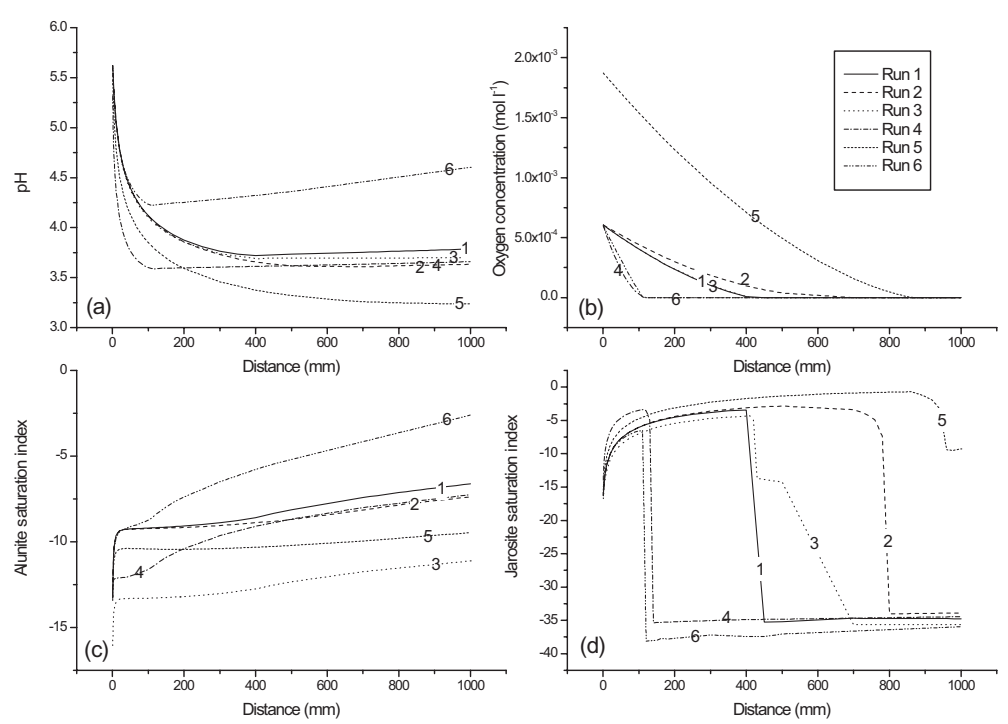

FIG. 4. Results of sensitivity analysis. Saturation index is defined by $\log (\mathrm{IAP})_{\mathrm{obs}}-\log (\mathrm{IAP})_{\text {calc }}$.

literature (e.g. Lasaga, 1989; Lasaga and Rye, 1993) and it can be shown that front characteristics are dependent on many factors, including temperature, grain size, reaction order, diffusion and dispersion coefficients. Here the approach is simplified to a level suitable for the quality and quantity of available data.

\section{Width of reaction front}

The general expression

$$
\frac{\partial x}{\partial O_{2}}=\frac{\partial t}{\partial O_{2}} \frac{\partial x}{\partial t}
$$

describes the relationship between $\mathrm{O}_{2}$ gradients in space and time and fluid velocity. $x$ is distance along a one-dimensional flow path, $\mathrm{O}_{2}$ is the oxygen concentration in moles $\mathrm{m}^{-3}$ of water and $t$ is time (s). Equation 15 can be integrated with respect to $\mathrm{O}_{2}$ to give

$$
\int_{O_{2, x=0}}^{O_{2, x=X}} \frac{d x}{d O_{2}} d O_{2}=\int_{O_{2, x=0}}^{O_{2, x=X}} \frac{d t}{d O_{2}} \frac{d x}{d t} d O_{2}
$$

This is equivalent to

$$
\int_{0}^{x} d x=\int_{O_{2, x=0}}^{O_{2, x=X}} \frac{d t}{d O_{2}} \frac{d x}{d t} d O_{2}
$$

$\mathrm{X}$ is the width of the reaction front. The first term on the right hand side, assuming that changes in $\mathrm{O}_{2}$ concentrations resulting from advection are insignificant in comparison to those resulting from reaction, represents rates of production or consumption of $\mathrm{O}_{2}$ by oxidation reactions, in moles $\mathrm{m}^{-3}$ of spoil s $\mathrm{s}^{-1}$. In the case of zero-order reactions this is a constant, $\mathrm{R}$ which is dependent on the rate of mineral oxidation, $R_{o x}$ (moles $\mathrm{m}^{-2} \mathrm{~s}^{-1}$ ), spoil density $\rho,\left(\mathrm{kg} \mathrm{m}{ }^{-3}\right)$, surface area $S A,\left(\mathrm{~m}^{2} \mathrm{~kg}^{-1}\right)$, mass fraction of the mineral $M_{\mathrm{M}}$, and $b$, the stoichiometric coefficient relating mineral oxidation to $\mathrm{O}_{2}$ consumption according to reaction 18

$$
\mathrm{R}=b \mathrm{R}_{\mathrm{ox}} \cdot S A \cdot M_{\mathrm{M}} \cdot \rho
$$

A constant $\mathrm{R}$ is sufficient to describe a pseudo first-order rate law if $\mathrm{R}$ represents the average rate of $\mathrm{O}_{2}$ consumption or production over the entire reaction front, and if this average rate does not change with time or distance. Rates are in moles $\mathrm{m}^{-3}$ of spoil. $d x / d t$ is equivalent to $v$, the Darcy velocity of the fluid in $\mathrm{ms}^{-1}$, and is assumed to be constant. Under these conditions, equation $17 \mathrm{can}$ be integrated to obtain equation 19

$$
X=\frac{-v O_{2, x=0}}{R}
$$

The negative sign arises from the convention that $\mathrm{O}_{2}$ addition to the solution is positive while consumption is negative. Less restrictive expres- 
sions for rate laws can be inserted into equation 17 and integrated to obtain more complex solutions for the width of the reaction front. If this is the case then some value of $O_{2, x=X}$ must be chosen at which oxidation reactions cease to occur, or $X$ will be calculated as infinity. Equation 19 applies to assemblages containing only one oxidizing species, as in polymineralic assemblages the relative proportions of oxidizing minerals will change over time, invalidating the assumption of constant rate, $\mathrm{R}$. Widths of reaction fronts calculated for pyrite only and $\mathrm{C}$ only systems using equation 19 are shown in Fig. $5 a$.

\section{Speed of reaction front}

The speed of a reaction front in equilibriumcontrolled systems can be derived from considerations of mass balance across a plane moving at the same speed as the front (cf. Bickle and Baker, 1990), or from the advection-dispersion equation (cf. Zhu et al., 2001). Either way, equation 20 is obtained

$$
V_{f}=v \frac{C_{2}^{f}-C_{1}^{f}}{C_{2}^{T}-C_{1}^{T}}
$$

Where $C$ is the concentration, in moles $\mathrm{m}^{-3}, v$ is the Darcy velocity in $\mathrm{ms}^{-1}$, subscripts 1 and 2 denote concentrations before and after the front, and superscripts $f$ and $T$ denote fluid and total (fluid plus solid) concentrations respectively. This expression is also valid for kinetically-controlled systems as it is based on mass balance rather than thermodynamic considerations. $C_{2}^{f}$ is calculated using the assumption that all the $\mathrm{O}_{2}$ in the fluid entering the front is transformed to reaction products, in this case, sulphate or $\mathrm{CO}_{2}$. Hence, the final concentration $C_{2}^{f}$ is related by a stoichiometric constant, $a$, to influent $\mathrm{O}_{2}$ concentrations.

$$
V_{f}=v \frac{a O_{2}^{x=0}-C_{1}^{f}}{C_{2}^{T}-C_{1}^{T}}
$$

Note that this expression is independent of kinetic parameters, and that the $C^{T}$ terms are dependent on mass fractions of reactant and spoil density. As before, it is convenient to calculate the rates of motion of reaction fronts for sulphur and carbon separately. If combined then the velocity of the reaction front will vary with time as the proportions of pyrite and carbon oxidized in the
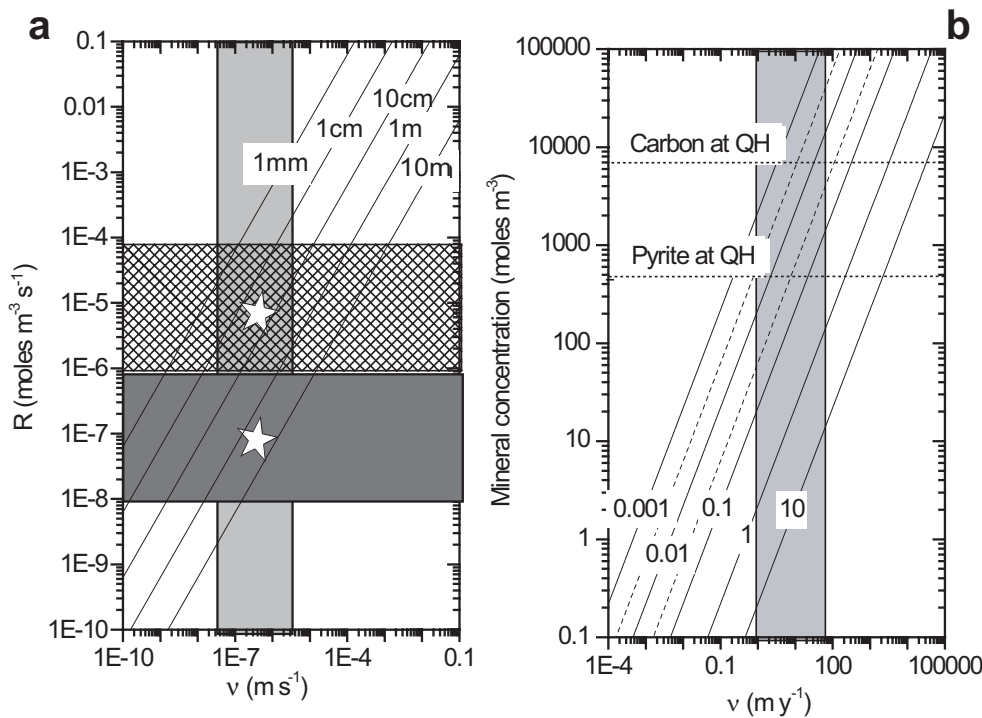

FIG. 5. (a) Contours of front width as a function of oxygen consumption rate, R, and fluid velocity, $v$. The grey, dark grey and cross hatched areas indicate plausible ranges of groundwater velocity, $\mathrm{O}$ consumption by pyrite and $\mathrm{O}$ consumption by $\mathrm{C}$ respectively. $(b)$ Contours of front velocity in $\mathrm{m} \mathrm{y}^{-1}$ as a function of mineral concentrations and fluid velocity, $v$. Diagonal solid lines are contours for pyrite-out front velocity and horizontal dashed lines for carbon-out. The grey shaded area indicates plausible groundwater velocities, and the dotted lines denote measured concentrations of pyrite and carbon at the field site. 
reaction front change. Calculated $V_{f}$ values as a function of plausible ranges of $v$ and $C_{2}^{T}$ are shown in Fig. $5 b$.

\section{Results}

\section{Field and mineralogical results}

Tip effluents have an average $\mathrm{pH}$ of 6.15 , with $\mathrm{Fe}$, sulphate and $\mathrm{Al}$ concentrations averaging 5,823 and $6 \mathrm{mg}^{-1}$ respectively. Water samples extracted from $\mathrm{BH} 7$, which lies $\sim 200 \mathrm{~m}$ from the discharge, have an average $\mathrm{pH}$ of 4 , and $\mathrm{Fe}$, sulphate and $\mathrm{Al}$ concentrations of 6,29 and $1 \mathrm{mg}^{-1}$ respectively. Clearly, dilution and other processes such as precipitation/dissolution and neutralization affect water composition between $\mathrm{BH} 7$ and the discharge point. Concentrations in solutions from $\mathrm{BH} 7$ have decreased markedly since the hole was first drilled three years ago, possibly as a result of recent clay capping (Younger, pers. comm.). There is also significant variation in water chemistry between $\mathrm{BH} 7$ and other boreholes (Pritchard, 1997), indicating that flow within the heap is channelled and/or that there is substantial heterogeneity within the spoil itself.

Gas sampling results (Table 1) exhibit a clear and consistent decrease in $\mathrm{O}_{2}$ concentration with depth, accompanied by increases in $\mathrm{CO}_{2}$. Methane was not detected. Given the lack of carbonate minerals detected at the study site, this $\mathrm{CO}_{2}$ is likely to have been produced by oxidation of carbonaceous matter (coal).

The most striking result of the XRD work is the apparent zonation of the heap with respect to S-bearing minerals (Fig. 2a). Jarosite at the top of the heap is replaced by alunite in the mid-section and by pyrite at the bottom. We propose that this mineralogical profile records the progression of pyrite oxidation. Jarosite replaces pyrite in the oxidized portion of the heap where the stable $\mathrm{Fe}$ solution species is the relatively insoluble Fe(III), while alunite forms from clay mineral-derived $\mathrm{Al}$ and transported sulphate in the central portions. Unreacted pyrite is stable under anoxic conditions, consistent with $\mathrm{O}_{2}$ distributions from gas sampling results. Unit-cell dimensions for jarosite were compared to values from Stoffregen et al. (2000) and indicate that the jarosites contain a significant sodic proportion (up to $20 \%$ ). No solid solution between jarosite and alunitic endmembers was observed. Alternatively, the mineralogical zonation may reflect variation in bulk composition. Table 2 shows bulk composition and at first glance reveals little systematic variation in composition with depth. To test this, a matrix of sample correlation coefficients was calculated for selected bulk compositional parameters (Table 3). Although there is no correlation of most bulk composition parameters with depth, suggesting that the mineralogical variation observed is a function of weathering processes, there is a good correlation between $\mathrm{Fe}$ and As contents $(\rho=0.96, p>0.95)$, with Fe content increasing with depth in the tip $(\rho=0.69, p>0.9)$. These trends are consistent with the hosting of arsenic within pyrite, which is stable in the lower portion of the tip and oxidized in the upper. When pyrite is oxidized, As is lost to solution and removed from the system. This interpretation is supported by the modal mineralogy, see below, and suggests that As distribution may provide a useful proxy for pyrite oxidation, at least at this location. This is potentially useful because direct observation of pyrite content via XRD or XRF can be problematic due to the wealth of Fe- and S-bearing phases commonly found in spoil environments, and difficulties with rapid quantitative interpretation of XRD results. Sulphur does not correlate well with any bulk compositional parameter or depth. This is noteworthy for two reasons. It suggests, firstly, that $\mathrm{S}$ is not consistently hosted within any one mineral phase, and secondly, that $\mathrm{S}$ is not necessarily lost into solution when pyrite is oxidized. This second point is relevant to assumptions made in mass-balance calculations, which frequently use sulphate as a conservative tracer for pyrite dissolution (e.g. Banwart and Malmstrom, 2001).

\section{Numerical modelling results}

Modelling the system is extremely computationally demanding as small cells are required for numerical convergence in the region of rapid $\mathrm{O}_{2}$ depletion, limiting the scope of the modelling. Therefore, the modelling is used to investigate results of interactions between reactions 1 to 11 over relatively short time and distance scales. Once the dominant processes occurring are recognized, rate calculations with analytical solutions can be made to predict long-term evolution in the spoil heap. Results (Fig. 3) discussed below are for the initial parameter set shown in Table 4. Although the model was run for 10,000 timesteps at the maximum possible timestep appropriate for the chosen parameters, the total modelled run time was only 100 days, 
and the depth considered was $1 \mathrm{~m}$. On this timescale there was very little variation in the positions of reaction fronts and gradients once steady state had been reached from the initial conditions. For this reason Fig. 3 shows results for the final timestep only. The limited depth did not restrict the information obtained to any significant degree as the bulk of reaction occurs in the oxic zone which lay well within the top $1 \mathrm{~m}$ for all considered sets of parameters.

The key feature of the results is the relatively rapid exhaustion of $\mathrm{O}_{2}$ in the first $40 \mathrm{~cm}$ of the modelled tip (Fig.3d). This results from the complete consumption of $\mathrm{O}_{2}$ by simultaneous oxidation of pyrite and organic matter. In this model, $\mathrm{C}$ and pyrite are consuming $\mathrm{O}_{2}$ at approximately the same rate in spite of the two orders of magnitude difference between the oxidation rates, simply because of the larger initial quantity of C. pH (Fig. $3 b$ ) decreases over the same interval, as the equivalents of acidity released by pyrite dissolution and formation of $\mathrm{Fe}$ oxyhydroxides outnumber those consumed by dissolution of illite, kaolinite and organic material. Clearly some of these processes are coupled, e.g. the protons consumed by the dissolution of kaolinite may be returned to the solution by the precipitation of $\mathrm{Al}(\mathrm{OH})_{3}$, but as the location of the two reactions is different, the net effect on $\mathrm{pH}$ in any location is non-zero. After the initial drop, $\mathrm{pH}$ is maintained at $\sim 3.7$ by buffering between $\mathrm{Al}$ species. Initial increases in $\mathrm{S}$ (Fig. 3e), C (Fig. 3f) and $\mathrm{Fe}(\mathrm{III})$ (Fig. $3 h$ ) concentrations record oxidative dissolution, followed by a plateau in the region where $\mathrm{O}_{2}$ is absent and reaction with respect to these species virtually ceases. Note the difference in shapes between $\mathrm{S}$ (Fig. 3e) and $\mathrm{C}$ (Fig. 3f) curves; the curved shape of the S curve results from the half-order dependence of pyrite dissolution on $\mathrm{O}_{2}$ concentration, while the rate of increase of $\mathrm{C}$ is essentially constant, as low rates of organic dissolution mean that the net quantity of organic matter remains essentially unchanged over the course of the modelling, giving a pseudo zero order rate law. The rate of increase of $\mathrm{Fe}$ concentrations is affected by precipitation of goethite (Fig. $3 k$ ) in addition to the accumulation of $\mathrm{Fe}$ by pyrite dissolution, but a trend of increasing $\mathrm{Fe}$ concentration is seen as the decreasing $\mathrm{pH}$ (Fig. $3 b$ ) enhances the solubility of goethite. The inverse relationship between $\mathrm{Fe}^{2+}$ and $\mathrm{Fe}^{3+}$ (Fig. $3 g, h$ ) reflects the $\mathrm{O}_{2}$ distribution in the heap. the pe value (Fig. $3 c$ ) remains essentially constant until $\mathrm{O}_{2}$ is exhausted, then drops to a value of 1. No Al-bearing phase reaches saturation in this model, which explains the constant-rate increase of $\mathrm{Al}$ concentration (Fig. 3i) resulting from the pseudo-zero order dissolution of kaolinite and illite. Potassium (not shown here) exhibits a similar trend. Alunite (Fig. $3 \mathrm{~m}$ ) and jarosite (Fig. $3 a$ ) saturation index curves are controlled by both pyrite dissolution, which provides $\mathrm{Fe}$ and $\mathrm{S}$, and by dissolution of clay minerals, which provide $\mathrm{K}$ and $\mathrm{Al}$. The initial rapid increase in jarosite saturation index $(0-8 \mathrm{~cm})$ with progressive pyrite dissolution flattens off as goethite reaches saturation. The sharp drop at the $\mathrm{O}_{2}$ exhaustion front reflects the change in $\mathrm{Fe}$ speciation from $\mathrm{Fe}$ (III) to $\mathrm{Fe}$ (II). Alunite saturation systematics are less complex, with an initial rapid increase and subsequent plateau. This shape is determined by the interplay between $\mathrm{Al}$ speciation changes with decreasing $\mathrm{pH}$, which favour alunite saturation, and the increased proton activity, which suppresses it, see reaction 11 . The relationship between the two curves qualitatively supports the explanation proposed for the field relationships of jarosite and alunite. Jarosite reaches maximum stability in the top portion of the heap above the $\mathrm{O}_{2}$-out front, whereas alunite stability continually increases with depth, such that it might be expected to become stable at some greater depth. However, formation of these minerals is not predicted by the model.

\section{Comparison with field data}

Table 5 compares analytical results for a typical groundwater sample extracted from $\mathrm{BH} 7$ with results from transport modelling. Run 1 is the initial run, with runs $2-6$ exploring the sensitivity of results to initial parameters (see below). The compositions of solutions extracted from $\mathrm{BH} 7$ exhibit a degree of non-systematic variation, superimposed onto an overall decline in both acidity and Fe content (not shown here). Random fluctuations are presumed to be due to variations in groundwater level and associated non-steady state precipitation/dissolution of secondary minerals, and the steady state decline may result from the clay capping of the tip a number of years ago (P. Younger, pers. comm.). Evidence from conservative species also suggests that evaporative concentration may occur (Lako, 1998). Results from analysis consistent with a steady state were utilized here. $\mathrm{pH}$ in the borehole solution is slightly higher than that modelled, and $\mathrm{Fe}, \mathrm{Al}$ and $\mathrm{K}$ concentrations are approximately 
one order of magnitude greater. Differences in $\mathrm{pH}$ arise from slower modelled overall rates of proton consumption relative to proton production than those actually observed on the tip. As the proton balance within the tip is a complex combination of several reactions it is not possible to say whether this is a result of overestimation of pyrite weathering or underestimation of carbon oxidation or clay mineral dissolution rates. The effect of variation of these parameters is explored in the sensitivity analysis below. The underestimation of Fe contents may be an indication that goethite is actually supersaturated in tip solutions to a greater degree than is assumed here, as Fe content of the modelled solution is controlled by goethite solubility. It is also possible that Fe(III)-bearing colloidal material was smaller than the $0.45 \mu \mathrm{m}$ filter size (Kretzschmar et al., 1994), and passed through the fine filters, leading to overestimation of dissolved $\mathrm{Fe}$. Underestimation of $\mathrm{Al}$ and $\mathrm{K}$ concentrations are expected as only the top $1 \mathrm{~m}$ of the tip is modelled here; concentrations will increase with depth until they are controlled either by saturation of product or reactant phases or by exhaustion of reactants. Saturation indices for goethite, $\mathrm{Al}(\mathrm{OH})_{3}$ hydroxide and alunite and jarosite agree well for oxic and anoxic zones. However, whereas saturation indices calculated from both modelling and analysis of field solutions indicate that hydroxysulphates are undersaturated, SEM and XRD observation of solid material reveal apparently stable jarosite and alunite. Reasons for this, and implications for the use of hydroxysulphate minerals as proxies for $\mathrm{O}_{2}$ distribution, are discussed below. Carbon dioxide saturation indices calculated from borehole gas concentrations are higher than those predicted by the model. The sign of the discrepancy is surprizing, as the assumptions regarding $\mathrm{CO}_{2}$ movement should lead to over- rather than underestimation. However, it may be that $\mathrm{CO}_{2}$ is affected by sources/sinks or processes not included in the model. Model results are compared to borehole concentrations rather than heap effluent concentrations because additional hydrogeological processes such as dilution modify water composition between $\mathrm{BH} 7$ and the discharge point.

\section{Results of sensitivity analysis}

Runs R2, R3, R4 and R5, exhibit a pH in the final cell lower than that calculated by R1 (Fig. $4 a$ ). In $\mathrm{R} 2$ this is a result of reduced proton consumption by organic material weathering coupled with additional $\mathrm{O}_{2}$ supply available for pyrite oxidation. In run $3 \mathrm{pH}$ is decreased by the reduction of proton consumption by clay mineral weathering, in run 4 by increased proton production by pyrite weathering, and in run 5, by the increased pyrite weathering made possible by the increased rate of $\mathrm{O}_{2}$ supply. In run 6 the final $\mathrm{pH}$ is greater than that of run 1 due to the increased fraction of $\mathrm{O}_{2}$ consumed by organic matter. $\mathrm{pH}$ also increases markedly with depth in run 6 because of the increased $\mathrm{C}$ content of the solution, which buffers $\mathrm{pH}$ by forming fully protonated carbonic acid. Oxygen concentrations (Fig. 4b) clearly illustrate the variation in reaction front width with changing input parameters. Reducing the rate of oxidation reactions (run 2) or increasing $\mathrm{O}_{2}$ supply (run 5) increases the width over which reactions occur, whereas increasing the reaction rates (runs 4 and 6) significantly reduces the width of the reaction front. Changing rates of clay mineral dissolution (run 3), has little effect on the reaction front width as these reactions do not consume $\mathrm{O}_{2}$. Increasing either pyrite or $\mathrm{C}$ oxidation rates by one order of magnitude has an almost identical effect, consistent with the fact that both are consuming approximately equal proportions of $\mathrm{O}_{2}$ over the width of the reaction front. It is difficult to conclusively compare reaction front widths with those observed in the field, as the field system has developed two separate fronts, with $\mathrm{C}$ existing throughout the tip (metre scale front), and pyrite disappearing over a $\mathrm{dm}$ scale. However, the disappearance of jarosite and appearance of pyrite occurs over a metre scale, similar to the $40 \mathrm{~cm}$ reaction front width predicted by the model. Given the faster rates of pyrite oxidation compared to $\mathrm{C}$, coupled with the lower initial quantities, it is expected that the modelled fronts would separate as observed in the field, if the model could be run for long enough. The shape of the alunite saturation index curve (Fig. $4 c$ ) is independent of changes in starting parameters although absolute values are affected. Final values are positively correlated with final $\mathrm{pH}$ values in all cases except run 3 , reflecting the increased solubility of alunite at low $\mathrm{pH}$. Run 3 differs in that $\mathrm{Al}$ and $\mathrm{K}$ release rates are lower by an order of magnitude than all the other runs, thus reducing the rate of increase of the saturation index. Jarosite saturation indices (Fig. 4d) graphically illustrate the position at which $\mathrm{O}_{2}$ concentrations are reduced to zero, with associated reduction of dissolved Fe(III) to Fe(II). The stepped shape of 
the curve observed for R3 is an artefact of the process of making the model discrete rather than a potentially real phenomenon.

Variation of model input parameters creates a range of conditions which allows reproduction of the saturation index values and element concentrations observed in the field. Iron values as high as those observed in the field occurred during run 5 only, in which the quantity of $\mathrm{O}$ available for pyrite oxidation was increased. Increased pyrite oxidation releases more sulphate, which brings final modelled values of sulphate concentration into line with those observed, and more protons, which reduces modelled $\mathrm{pH}$ thus producing higher Fe concentrations, as goethite solubility increases with decreasing $\mathrm{pH}$, see reaction 4 . The order of magnitude agreement obtained between modelled and observed concentrations suggests that R5 starting assumptions applied are most appropriate to field conditions, although the possibility of a non-unique solution cannot be discounted. The computational demands of the numerical model preclude longer-term simulations of spoil heap evolution at this stage. Particle tracking models, which replace the iterative solution of the advective-dispersive equation with sequential movement of particles which are then used to calculate concentrations, are one possible way of dealing with this problem (e.g. Gandy and Evans, 2002). Alternatively, front speeds and widths may be calculated analytically.

\section{Results of analytical modelling}

The contours in Fig. $5 a$ indicate the width of reaction front which can be expected for given combinations of reaction rates and fluid velocities. Likely estimates of fluid velocities for the Quaking Houses site are contained within the grey shaded area. The range of expected $\mathrm{R}$ values, in moles $\mathrm{m}^{-3}$ of spoil s $\mathrm{s}^{-1}$ are shown in dark grey (C) and with cross-hatching (pyrite). Predicted pyrite reaction front widths lie between $1 \mathrm{~mm}$ and $1 \mathrm{~m}$, whereas those for $\mathrm{C}$ are of the order of $10 \mathrm{~cm}$ to $10 \mathrm{~m}$. Stars mark reaction rates utilized in $\mathrm{R} 5$; reaction rates of this order give a reaction front width on a scale of $\mathrm{dm}$ for pyrite, and metres for C. In this case, pyrite oxidation will initially control the shape and width of the reaction front by consuming all the available $\mathrm{O}_{2}$, and the full $\mathrm{C}$ oxidation front will be inhibited. With passing time the two reaction fronts will become decoupled, as observed in the field, such that the carbon front extends upwards into the portion of the heap where pyrite is already exhausted. Note that widths of pyrite reaction fronts derived from both numerical and analytical approaches are similar for the same reaction rate, providing valuable confirmation of the comparability of the two approaches. Figure $5 b$ shows contours of reaction front velocity as a function of fluid velocity and mineral concentration, with dashed horizontal lines indicating the average values for mineral concentrations at Quaking Houses. The grey shaded rectangle indicates the expected range of fluid velocities, as before. Carbon fronts cannot be expected to move faster than $0.01 \mathrm{~m} \mathrm{y}^{-1}$, giving a lifetime of carbon in a $10 \mathrm{~m}$ thick heap of $1000 \mathrm{y}$. This is quick on a geological timescale but slow on a human one, and is consistent with the lack of observations of C-free coal spoilheaps. In any case, erosional processes would be expected to become significant on the centennial to millennial timescale. Pyrite fronts are expected to move between 0.001 and $0.1 \mathrm{my}^{-1}$. The pyrite exhaustion front observed in the field has moved $\sim 5 \mathrm{~m}$ in $50 \mathrm{y}$. The average velocity of $0.1 \mathrm{~m} \mathrm{y}^{-1}$ lies within, although at the higher end of, the range estimated from the analytical expression.

\section{Discussion and conclusions}

Careful examination of data from analysis of solid and fluid samples collected from the field has allowed identification of minerals and field processes which were incorporated into a numerical one-dimensional advective transport model. The numerical modelling, although restricted in scope by computational demands, successfully reproduces concentrations and saturation indices of key elements, gases and phases observed in the field, and also predicts widths of reaction fronts consistent with those observed. Increasing the rate of $\mathrm{O}$ addition, run 5, gives the best agreement between predicted and modelled results, suggesting that $\mathrm{O}$ percolation by diffusion, which is ignored in this study, may be significant. This consistency suggests that the initial assumptions of run 5 may describe rates and processes occurring in the field. Although this is likely to be a non-unique solution, valuable information on absolute and relative rates of reactions considered has been gained. Utilization of this information in analytical modelling of widths and speeds of reaction fronts allows us to build up a stronger conceptual model of the heap evolution, which can be envisaged as proceeding in four stages 
(Fig. 6). During the first stage (Fig. 6a) neither pyrite nor $\mathrm{C}$ is exhausted in any portion of the heap, and $\mathrm{O}_{2}$ disappears within the first few $\mathrm{dm}$. This stage lasts until pyrite disappears from the top of the heap, and the pyrite reaction front, which is a few $\mathrm{dm}$ wide, begins to move at a speed of $\sim 10 \mathrm{~cm} \mathrm{y}^{-1}$. As $\mathrm{C}$ reaction front velocity is approximately two orders of magnitude slower than that of pyrite, we will not observe any significant change in $\mathrm{C}$ on the annual to decadal timescale. Thus, at this stage, the heap will be divided into a top portion, where pyrite but not $\mathrm{C}$ is exhausted, a middle section, which is the active pyrite oxidation front, and a lower, anoxic portion in which pyrite and carbon remain unreacted (Fig. 6b). This is the stage observed at Quaking Houses today. Eventually, the full $\mathrm{C}$ reaction front will develop (Fig. $6 c$ ). At this time $\mathrm{C}$ oxidation will completely control $\mathrm{O}_{2}$ distribution in the heap as pyrite will be exhausted over the full length of the front, which is expected to exist on a metre scale. This situation is expected to develop over a period of centuries, and marks the time when a heap will cease to be seriously polluting. If the tip is high enough then the $\mathrm{C}$ front will eventually begin to move (Fig. $6 d$ ) at a velocity of $\sim 1 \mathrm{~mm} \mathrm{y}^{-1}$. Pyrite reaction will accompany this movement, but will be severely restricted as $\mathrm{C}$ oxidation will be controlling the available oxygen. Finally, after millennia, both $\mathrm{C}$ and pyrite will be fully oxidized.

Numerical modelling qualitatively confirms the hypothesis proposed for the observed distributions of jarosite and alunite minerals, although stability was not predicted either by modelling or field solution data. It may be that this is due to the sodic nature of the hydroxysulphate minerals, which reduce the activity of the pure endmember, allowing precipitation at lower saturation indices (Glynn, 2000), although it is unlikely that this alone could lead to hydroxysulphate stability. The extent of this effect is currently being investigated. Alternatively, it may be that jarosite and alunite were stable at an earlier time, and are now metastable. $\mathrm{BH} 7$ concentrations of $\mathrm{Fe}$ and sulphate were very high after drilling, which may indicate that the strata were hydrologically isolated before drilling and that evaporative concentration processes had built up excessive concentrations, stabilizing the secondary minerals. It may also be that other assumptions used for the modelling, such as stoichiometric illite dissolution are adversely affecting the predictive ability of the model. Further investiga-

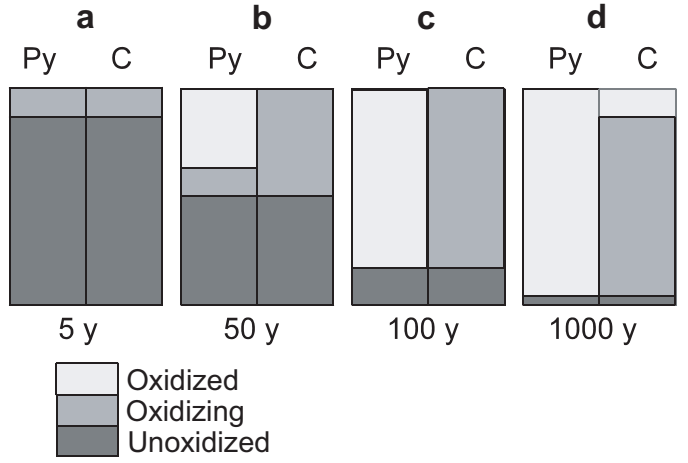

FIG. 6. Schematic diagram outlining evolution of redox fronts in a coal tip containing both pyrite and C. Onedimensional transport only is considered.

tion is required to distinguish between these processes. Arsenic concentration in the solid phase, however, may prove to be a useful proxy for pyrite fraction and hence $\mathrm{O}_{2}$ distribution, as pyrite distribution will control $\mathrm{O}_{2}$ concentrations for the first $100 \mathrm{y}$ or so of the tip's evolution.

The success of any modelling exercise is determined by its ability to solve the specified problem, or predict to a preselected degree of accuracy. In this case the purpose of the modelling was investigation of the effects of coupled kinetic processes, and validation of assumptions suitable for use in the calculation of front speeds and widths for this particular site. Both aims were fulfilled successfully. The analytical model, although unsuitable for detailed prediction of concentrations and mineral stabilities, provides a generic method for assessing the long-term evolution of spoil heap mineralogical and effluent characteristics once important processes have been identified. Errors, propagated assuming that terms in reactions 19 and 20 vary independently, are up to an order of magnitude. To improve the precision of calculated results, a number of model limitations must be addressed. These include the assumptions of constant groundwater velocity/direction, porosity, permeability and mineral assemblage, negligible dispersion and the exclusion of ion exchange and surface reactions. However, these limitations are imposed as much by the lack of fundamental knowledge of field parameters, especially those associated with secondary minerals and gases, as by the restrictions of the conceptual model. 


\section{Acknowledgements}

K. Evans and C.J. Gandy were funded by NERC as part of the Environmental Diagnostics thematic programme. Thanks are due to Gordon Cressey and Eva Valsami-Jones at the Natural History Museum, London, for help with XRD analysis of hydroxysulphates, and to Paul Younger and Adam Jarvis for informative discussions on the history and hydrogeology of the field site. Two anonymous reviewers are also thanked for valuable and constructive comments on the paper.

\section{References}

Appelo, C.A.J. and Postma, D. (1993) Geochemistry, Groundwater and Pollution. A.A. Balkema, Rotterdam, 536 pp.

Baldi, F., Clark, T., Pollack, S.S. and Olson, G.J. (1992) Leaching of pyrites of various reactivities by Thiobacillus Ferrooxidans. Applied and Environmental Microbiology 58, 1853-1856.

Ball, J.W. and Nordstrom, D.K. (1991) WATEQ4F: Users manual with revised thermodynamic data base and test cases for calculating speciation of major, trace and redox elements in natural waters. USGS Open-File Report 90-129 Denver, Colorado.

Banks, D., Younger, P.L., Arnesen, P.L., Iverson, E.R. and Banks, S.B. (1997) Mine-water chemistry: the good, the bad and the ugly. Environmental Geology 32, 157-174.

Banwart, S.A. and Malmstrom, M.E. (2001) Hydrochemical modelling for preliminary assessment of minewater pollution. Journal of Geochemical Exploration, 74, 73-97.

Bennet, J.W., Comarmond, M.J., Clark, N.R., Carras, J.N. and Day, S. (1999) Intrinsic oxidation rates of coal reject measured in the laboratory. Pp. 9-17 in: Mining and the Environment II (D. Goldsack, N. Belzile, P. Yearwood and G. Hall, editors). Conference Proceedings, Sudbury, Ontario.

Bickle, M. and Baker, J. (1990) Migration of reaction and isotopic fronts infiltration zones: assessments of fluid flux in metamorphic terrains. Earth and Planetary Science Letters, 98, 1-13.

Blowes, D.W. (1991) The formation and potential importance of cement layers in active sulphide mine tailings. Geochimica et Cosmochimica Acta, 55, 965-978.

Capitan, M.A. et al. (2001) Acid mine drainage remediation: what can we learn from the mineralogy of gossans? Pp. 42-43 in: Metals in the Weathering Environment (C.M. Rice and R. Herrington, editors). Conference Abstract volume, Geological Society, London.

Chang, S. and Berner, R.A. (1999) Coal weathering and the geochemical carbon cycle. Geochimica et Cosmochimica Acta, 63, 3301-3310.

Fanning, D.S. and Keramidas, V.Z. (1989) Micas. Pp. 195-258 in: Minerals in Soil Environments (J.B. Dixon and S.B. Weed, editors). Soil Science Society of America, Madison, Wisconsin.

Gandy, C.J. and Evans, K.A. (2002) Laboratory and numerical modelling studies of iron release from a spoil heap in County Durham. Pp. 205-214 in: Minewater Hydrogeology and Geochemistry (N.S. Robins and P. Younger, editors). Special Publication, 198. Geological Society, London.

Glynn, P. (2000) Solid-solution solubilities and thermodynamics: sulphates, carbonates and halides. Pp. 481-511 in: Sulfate Minerals Crystallography, Geochemistry and Environmental Significance (C.N. Alpers, J.L. Jambor, and D.K. Nordstrom, editors). Reviews in Mineralogy and Geochemistry, 40. Mineralogical Society of America and the Geochemical Society, Washington, D.C.

Guo, W., Parizek, R.R. and Rose, A.W. (1994) The role of thermal convection in resupplying $\mathrm{O}_{2}$ to strip coal-mine spoil. Soil Science, 158, 47-55.

Jarvis, A.P. and Younger, P.L. (1999) Design, construction and performance of a full-scale compost wetland for mine-spoil drainage treatment at Quaking Houses. Journal of the Chartered Institution of Water and Environmental Management, 13, 313-318.

Jaynes, D.B., Rogowski, A.S. and Pionke, H.B. (1972) Atmosphere and temperature changes within a reclaimed coal strip mine. Soil Science, 136, 164-177.

Jones, J.C., Henderson, K.P., Littlefair, J. and Rennie, S. (1991) Kinetic parameters of oxidation of coals by heat-release measurement and their relevance to selfheating tests. Fuel, 77, 19-22.

Kemp, P. and Griffiths, J. (1999) Quaking Houses: Art, Science and the community, a Collaborative Approach to Water Pollution. John Carpenter, Oxfordshire, UK $142 \mathrm{pp}$.

Kretzschmar, R., Robarge, W.P. and Amoozegar, A. (1994) Filter efficiency of three saprolites for natural clay and iron oxide colloids. Environmental Science and Technology, 28, 1907-1915.

Lako, M. (1998) Monitoring and modelling groundwater flow and solute transport in the Morrison Busty spoil heap, County Durham. MSc thesis (unpubl.) University of Newcastle upon Tyne, UK.

Lasaga, A.C. (1989) Fluid flow and chemical reaction kinetics in metamorphic systems: a new simple model. Earth and Planetary Science Letters, 94, 417-424.

Lasaga, A.C. and Rye, D.M. (1993) Fluid flow and chemical reaction kinetics in simple systems. American Journal of Science, 293, 461-404. 
Malmstrom, M.E., Destouni, G., Banwart, S.A. and Stromberg, B.H.E. (2000) Resolving the scaledependence of mineral weathering rates. Environmental Science and Technology, 34, 1375-1378.

Martello, D.V., Vecchio, K.S., Diehl, J.R., Graham, R.A., Tamilia, J.P. and Pollack, S.S. (1994) Do dislocations and stacking faults increase the oxidation rate of pyrite. Geochimica et Cosmochimica Acta, 58, 4657-4665.

McKibben, M.A. and Barnes, H.L. (1986) Oxidation of pyrite in low temperature acidic solutions: rate laws and surface textures. Geochimica et Cosmochimica Acta, 50, 1509-1520.

Nagy, K.L., Blum, A.E. and Lasaga, A.C. (1991) Dissolution and precipitation kinetics of kaolinite at $80^{\circ} \mathrm{C}$ and $\mathrm{pH} 3$ : the dependence on solution saturation state. American Journal of Science, 291, 649-686.

Nordstrom, D.K. and Southam, G. (1997) Geomicrobiology of sulfide mineral oxidation. Pp. 361-390 in: Geomicrobiology: Interactions between Microbes and Minerals (J.F. Banfield and K.H. Nealson, editors). Reviews in Mineralogy, 35, Mineralogical Society of America, Washington, D.C.

Parkhurst, D.L. and Appelo, C.A.J. (1999) Users guide to PhreeqC (version 2): a computer program for speciation, batch reaction, one dimensional transport and inverse geochemical calculations. USGS Water-Resources Investigations Report 99-4259 Denver, Colorado.

Press, W.H., Flannery, B.P., Teulolsky, S.A. and Vetterling, W.T. (1986) Numerical Recipes. Cambridge University Press, Cambridge, UK, 818 pp.

Pritchard, J. (1997) Leachate Release from a Large Body of Contaminated Land: Morrison Busty Spoil Heap, County Durham. MSc thesis (unpubl.) University of Newcastle, UK.

Spears, D.A., Taylor, R.K. and Till, R. (1971) A mineralogical investigation of a spoil heap at Yorkshire Main Colliery. Quarterly Journal of Engineering Geology, 3, 239-252.
Stoffregen, R.E., Alpers, C.N. and Jambor, J.L. (2000) Alunite-jarosite crystallography, thermodynamics, and geochronology. Pp. 453-479 in: Sulfate Minerals - Crystallography, Geochemistry and Environmental Significance (C.N. Alpers, J.L. Jambor and D.K. Nordstrom, editors). Reviews in Mineralogy and Geochemistry, 40. Mineralogical Society of America and the Geochemical Society, Washington, D.C.

Stromberg, B. and Banwart, S.A. (1999) Experimental study of acidity-consuming processes in mining waste rock: some influences of mineralogy and particle size. Applied Geochemistry, 14, 1-16.

Taylor, J.C. (1991) Computer programs for standardless quantitative analysis of minerals using the full powder diffraction profile. Powder Diffraction 6, $2-9$.

Walter, A.L., Frind, E.O., Blowes, D.W., Ptacek, C.J. and Molson, J.W. (1994) Modelling of multicomponent reactive transport in groundwater 1 . Model development and evaluation. Water Resources Research, 30, 3137-3148.

Walther, J.V. (1996) Relation between rates of aluminosilicate mineral dissolution, $\mathrm{pH}$, temperature and surface charge. American Journal of Science, 296, 693-728.

Williamson, M.A. and Rimstidt, J.D. (1994) The kinetics and electrochemical rate-determining step of aqueous pyrite oxidation. Geochimica et Cosmochimica Acta, 58, 5443-5454.

Younger, P.L. (2000) Predicting temporal changes in total iron concentrations in groundwaters flowing from abandoned deep mines: a first approximation. Journal of Contaminant Hydrology, 44, 47-69.

Zhu, C., Hu, R.Q. and Burden, D.S. (2001) Multicomponent reactive transport modelling of natural attenuation of an acid groundwater plume at a uranium mill tailings site. Journal of Contaminant Hydrology, 52, 85-1008.

[Manuscript received 10 December 2001: revised 16 December 2002] 